\title{
Modyfikacje asortymentowe w przedsiębiorstwach handlu detalicznego żywnością
}

Assortment modification in food retailing enterprises

\section{Wprowadzenie}

Decyzje związane z polityką asortymentową przedsiębiorstw handlu detalicznego są kluczowym obszarem kreowania przyszłej sytuacji ekonomicznej firmy. Polityka asortymentowa wiąże się bowiem z pozyskaniem klientów, którzy poprzez wydatkowanie swoich środków generować będą przychody przedsiębiorstwa, jednakże wyłącznie w sytuacji, kiedy kompozycja asortymentowa umożliwi im zaspokojenie aspiracji zakupowych. W tym kontekście wprowadzanie do oferty sklepu kolejnych pozycji jest koniecznością wynikającą z oczekiwań nabywców, którzy spodziewają się nowych produktów, doświadczeń i korzyści związanych z zakupem. Rozbudowa asortymentu wiąże się jednak równocześnie z wyższym ryzykiem braku klienckiej akceptacji innowacji w ofercie sklepu, a także ze wzrostem kosztów będących pochodną cen zakupu towarów, sposobów gospodarowania zapasami czy zamrożenia kapitału.

Specyficzne problemy kształtowania kompozycji asortymentowej dotyczą przedsiębiorstw handlu detalicznego oferujących produkty żywnościowe. Żywność odgrywa bowiem szczególną rolę w zaspokajaniu potrzeb konsumentów, pełniąc funkcję dobra podstawowego, gwarantującego biologiczne przetrwanie, i zapewniając podstawę zdrowego życia. W efekcie naturalnej skłonności do oczekiwania od produktów żywnościowych wysokiej jakości, gwarantującej bezpieczeństwo zdrowotne, wysokich standardów cech organoleptycznych czy zaspokojenia wyrafinowanych gustów smakowych, konsumenci preferują produkty sprawdzone, pochodzące z pewnego źródła zaopatrzenia, często od lokalnych 
producentów. W związku z tym szybka rotacja towarów w sklepach, których głównym asortymentem są produkty żywnościowe, nie łączy się zazwyczaj z innowacyjnością produktów czy nowatorskim podejściem do konstruowania kompozycji asortymentowej proponowanej klientom. Poszerzanie oferty sklepu, w której znajdują się artykuły żywnościowe, o nowe rodzajowo produkty wymaga szeregu przygotowań, reorganizacji, ale także wnikliwej analizy pozwalającej uniknąć niepowodzenia rynkowego.

Biorąc pod uwagę dotychczasowe spostrzeżenia, za cel opracowania przyjęto próbę określenia skali, w jakiej przedsiębiorstwa handlu detalicznego żywnością poszukują produktów, których dotychczas nie sprzedawano, a które mogłyby cieszyć się zainteresowaniem klientów. Prezentowane badania zmierzają do identyfikacji, w jaki sposób pozyskiwane są informacje od klientów o ich oczekiwaniach dotyczących nowych pozycji asortymentu, a także, jakimi motywami kierują się przedsiębiorcy, którzy pomijają poszukiwanie nowych produktów do swojej oferty handlowej. Celem opracowania jest także wskazanie postaw, jakie w zakresie kompozycji asortymentu wiążą się z generowaniem efektów rynkowych korzystniejszych niż u konkurencji.

\section{Kształtowanie asortymentu w przedsiębiorstwach handlu detalicznego - przegląd literatury}

Istotą handlu detalicznego jest pośredniczenie między producentami a konsumentami w wymianie towarowej, a zasadniczą jego podstawę stanowi kształtowanie asortymentu handlowego. Ten ostatni rozumiany jest jako zestaw wszystkich produktów oferowanych przez przedsiębiorstwo (Grzesiuk, 2000, s. 35). Zestaw ten profiluje ofertę handlową pod kątem potrzeb klientów, zapewniając efektywność prowadzonej działalności. W jego budowaniu niezbędne jest uwzględnienie zarówno preferencji nabywców (Pilarczyk, Sławińska \& Mruk, 2001, s. 147) i zapewnienie akceptacji konsumenckiej według kryterium value for money (Śmigielska \& Wiśniewska, 2016, s. 60), jak i realizacji celów przedsiębiorców w postaci optymalizacji poziomu rentowności (Sławińska, 2015, s. 163). Uwarunkowania decyzji w zakresie kształtowania oferty asortymentowej wynikają przy tym tak z fizyczno-chemicznych charakterystyk produktów, niezbędnej powierzchni sprzedażowej i magazynowej oraz kosztów obrotu, jak i sytuacji rynkowej określonej popytem i intensywnością konkurencji, które determinują potencjalne obroty i marżę handlową (Mikołajczyk, 2008, s. 129). 
W kontekście orientacji na klienta ważnym zadaniem handlu detalicznego jest dostarczenie zbioru korzyści dla nabywcy, który może wynikać zarówno z kompleksowości oferty, jak i dostępności produktów niszowych. Zadanie to warunkuje decyzje w zakresie szerokości i głębokości asortymentu (Mruk \& Rutkowski, 1999, s. 35) oraz spójności asortymentu określającej stopień podobieństwa linii produktów (Waniowski, Sobotkiewicz \& Daszkiewicz, 2010, s. 178). Struktura asortymentu musi zostać określona w przekroju branżowym, grup towarowych oraz artykułowych i pojedynczych artykułów (Łukasik, 2008, s. 42). Wyzwaniem dla podmiotów handlowych jest w aspekcie pro-klienckim zróżnicowanie preferencji zakupowych $w$ sytuacji zawierania transakcji z dużą liczbą indywidulanych klientów (Sławińska, 2015, s. 157, 163). Często postulowanym rozwiązaniem jest oparcie oferty asortymentowej na kategoriach produktowych, stanowiących grupę produktów postrzeganych jako powiązane w zaspokajaniu potrzeb (Kobyłt, 2006, s. 27-28). Decydując się na głęboki asortyment, przedsiębiorstwo kreuje wizerunek specjalisty, podkreślając profil działalności i możliwość pełnego wyboru dla klienta (Grzesiuk, 2000, s. 35-36). Wybierając opcję asortymentu szerokiego, stwarza zaś warunki możliwości realizacji kompleksowych zakupów i podkreśla atut kompletności oferty (Cox \& Brittain, 2000, s. 158).

Orientacja na klienta powoduje, że specyfika jego zachowań warunkuje wybór rozmiarów asortymentu. Badania Whitley, Trudel i Kurt (2018, s. 710-724) wskazują, że istotną determinantę decyzji asortymentowych stanowi charakter motywacji zakupowych grupy docelowej. Autorzy stwierdzają, że nabywcy kierujący się bodźcami hedonistycznymi (osobistą przyjemnością) porównują większą liczbę alternatyw niż klienci motywowani funkcjami użytecznościowymi produktów. Natomiast Mathmanna, Chylinski, de Ruyterc i Higgins (2017, s. 212-222) formułują wnioski o rosnącej satysfakcji z możliwości wyborów spośród dużego asortymentu w sytuacji przyjęcia przez klienta orientacji oceniającej, która zwiększa jego zaangażowanie i zdecydowanie przy podejmowaniu decyzji. W odniesieniu do ogółu klientów Ruiz-Real, Gázquez-Abad, Esteban-Millat i Martínez-López (2018, s. 43-56) zauważają, że lojalność konsumencka względem sklepu wzrasta (i ograniczane są intencje zmiany sklepu) wraz ze wzrostem postrzeganej różnorodności asortymentu. Przeciwne stanowisko zajmują Diehl i Poynor (2010, s. 312-322), którzy argumentują, że większy asortyment nie tylko powoduje odroczenie decyzji zakupowej oraz zwiększa skalę modyfikacji decyzji nabywczych, ale i obniża poziom satysfakcji konsumenta ze względu na mechanizm oczekiwania-odrzucenie. Wraz ze wzrostem rozmiaru asortymentu wzrastają bowiem oczekiwania odnośnie do stopnia dopasowania produktu do indywidualnych preferencji, co może prowadzić do wzrostu dysonansu pozakupo- 
wego. Podobnie Dekimpea, Gielens, Raju i Thomase (2011, s. 17-S28) przywołują badania zalecające redukcję asortymentu i stwierdzają, że mniejszy asortyment może zwiększyć satysfakcję nabywców, prawdopodobieństwo wyboru produktu i sklepu oraz zredukować negatywne efekty pozakupowe, a w efekcie poprawić zyskowność kategorii produktowej oraz sklepu.

Kształtując rentowność działalności, przedsiębiorstwo musi jednak uwzględniać, oprócz specyfiki klientów, również stronę kosztową budowania oferty asortymentowej. Asortyment głęboki i szeroki automatycznie generują wzrost zapasów i wynikające stąd koszty magazynowania oraz utrzymania i obsługi większej powierzchni sprzedażowej. Co więcej, kompleksowa oferta oznacza utrzymywanie towarów wolniej rotujących, obniżając sprawność działalności. Optymalizacja efektów finansowych stwarza zatem konieczność kalkulacji korzyści i kosztów wynikających z wyboru możliwych opcji asortymentowych i nie zawsze pogłębianie lub poszerzanie oferty przyczynia się do uzyskania oczekiwanych wyników ekonomicznych (Grzesiuk, 2000, s. 35-36; Cox \& Brittain, 2000, s. 158).

Determinanty wyboru rozmiaru asortymentu są więc niezwykle złożone, a jednocześnie, jak uważa Petrova (2019, s. 459-464), w dynamicznym otoczeniu rynkowym wzrasta znaczenie tego typu decyzji jako czynnika zapewniającego efektywność działalności. Jednocześnie badania tej autorki sugerują, że struktura korporacyjna i format detalisty wykazują większe bezpośrednie związki z rozmiarem asortymentu niż oddziaływanie konsumentów i konkurencji. Niemniej jednak powszechnie uznaje się popyt rynkowy za jeden z najważniejszych czynników determinujących decyzje o wprowadzaniu innowacji produktowych (w tym nowych marek w ramach linii produktowych) i przyjmuje, że konsumenckie preferencje warunkują sukces rynkowy takich działań (Rajagopal, 2008, s. 54-75). Jak wskazują Shankar i Yadav (2011, s. S1-S2), zmiany asortymentowe powinny zostać wsparte rzetelną analizą zmian w preferencjach konsumenckich, ale i w zakresie technologii oraz możliwości współkreacji.

Zdaniem Pilarczyk, Sławińskiej i Mruka (2001, s. 147) ważnym kryterium poprawności polityki asortymentowej jest elastyczność oferty. Taki warunek wynika z wysokiej dynamiki otoczenia, zarówno w kontekście zachowań nabywczych, jak i posunięć konkurencji oraz dostawców. Przedsiębiorstwa handlu detalicznego stają więc wobec permanentnych wyborów w zakresie możliwości pogłębiania bądź poszerzania asortymentu lub działań spłycających czy zawężających ofertę. Wybory asortymentowe oznaczają także decyzje o substytucji jednostek asortymentowych (np. w ujęciu marek produktów) lub całych linii produktowych (związanych ze zmianą profilu działalności). Badania empiryczne wskazują, że ponad połowa przedsiębiorstw handlowych wprowadza zmiany w swojej dzia- 
łalności, a w niemal 80\% - nowe rozwiązania dotyczą asortymentu (Kucharska, 2014, s. 871). Jednak jedynie 10-15\% innowacji produktowych zyskuje akceptację klientów (Olejniczak, 2008, s. 167-168), a 80\% wartości sprzedaży generowana jest przez zaledwie $20 \%$ asortymentu (Hutt \& Speh, 1997, s. 152, 463, 475). Niemniej jednak innowacje w przedsiębiorstwach handlowych ukierunkowane są zasadniczo na zwiększenie długookresowej rentowności działań, przyjmując za cel m.in.: poprawę jakości oferty, wzrost konkurencyjności, zwiększenie sprawności i efektywności działań (Tul-Krzyszczuk \& Krajewski, 2014, s. 778-779). Jak podkreśla Kłosiewicz-Górecka (2014, s. 9, 12), taka efektywność gospodarowania wymaga szybkiej analizy danych rynkowych i podejmowania decyzji w zakresie zakupu towarów, merchandisingu, budowania relacji czy gospodarki zasobami.

\section{Metodyka badań własnych}

Na podstawę wnioskowania $\mathrm{w}$ artykule, poza źródłami wtórnymi, złożyły się wyniki własnych badań empirycznych z uczestnictwem 321 respondentów reprezentantów właścicieli, kadry zarządzającej oraz handlowców z przedsiębiorstw handlu detalicznego, prowadzących działalność na terenie województwa podkarpackiego. Warunkiem uczestnictwa w badaniu było posiadanie przez firmę asortymentu obejmującego produkty żywnościowe. Jednocześnie w doborze próby nie dyskryminowano firm dysponujących asortymentem, w skład którego wchodziły również kosmetyki czy środki czystości, a także artykuły gospodarstwa domowego, co było powszechną praktyką podmiotów realizujących sprzedaż żywności.

Wyniki pozyskano techniką wywiadów bezpośrednich, zrealizowanych na przełomie 2015 i 2016 roku w miejscu prowadzenia sprzedaży, wykorzystując przy tym autorski kwestionariusz wywiadu, którego konstrukcję podporządkowano określeniu związków pomiędzy szeroko rozumianymi działaniami podmiotów a ich pozycją rynkową i efektami ekonomicznymi. Część zagadnień poruszanych w kwestionariuszu dotyczyła bezpośrednio również polityki asortymentowej, co pozwoliło wyprowadzić wnioski na temat ekonomicznych rezultatów decyzji związanych z kompozycją asortymentową. Zmierzając do ustalenia takich związków, w opracowaniu wykorzystuje się szereg klasyfikacji, takich jak: wielkość badanych firm wyrażona liczbą pracujących osób w przedziałach adekwatnych do kategoryzacji GUS, poziom rentowności przedsiębiorstw, miejsce funkcjonowania (miasto i wieś), pozycja rynkowa i perspektywy rozwoju, a także zasięg przestrzenny oddziaływania oraz zdolność do konkurowania na rynku 
zintegrowanej Europy. Wskaźnik rentowności przychodów brutto pozwolił pogrupować badane firmy w podgrupy od I (najniższa rentowność) do IV (najwyższa rentowność), które wyznaczono bazując na wartości średniej i odchylenia standardowego $\mathrm{z}$ ustaleniem podgrup jako: I: (od $-\infty$ do średnia-odchylenie standardowe), II: <od średnia-odchylenie standardowe do średnia), III: <od średnia do średnia+odchylenie standardowe), IV: <od średnia+odchylenie standardowe do $+\infty$ ).

Przyjęte w opracowaniu kategorie podzielono dodatkowo na kryteria o charakterze obiektywnym (wykres 1) i subiektywnym (wykres 2).

W pierwszym przypadku podstawą przynależności badanej firmy do określonej podgrupy były fakty oraz obliczone wskaźniki, w drugim natomiast - subiektywne deklaracje przedsiębiorców o przynależności do grup o zróżnicowanej pozycji rynkowej, sytuacji rozwojowej, przestrzennym zasięgu działania czy zdolności do konkurowania na otwartym rynku.

Wykres 1. Struktura badanej grupy podmiotów z uwzględnieniem obiektywnych czynników klasyfikacji [\%]

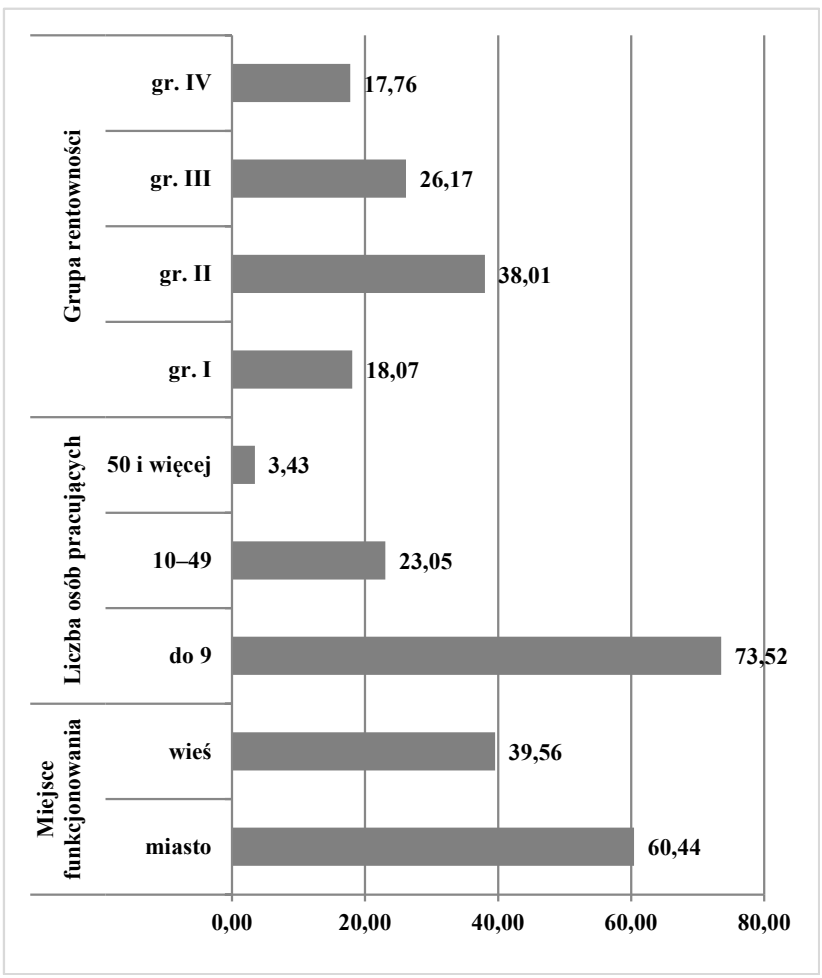

(Źródło: Obliczenia na podstawie wyników własnych badań). 
Wykres 2. Struktura badanej grupy podmiotów z uwzględnieniem subiektywnych czynników klasyfikacji [\%]

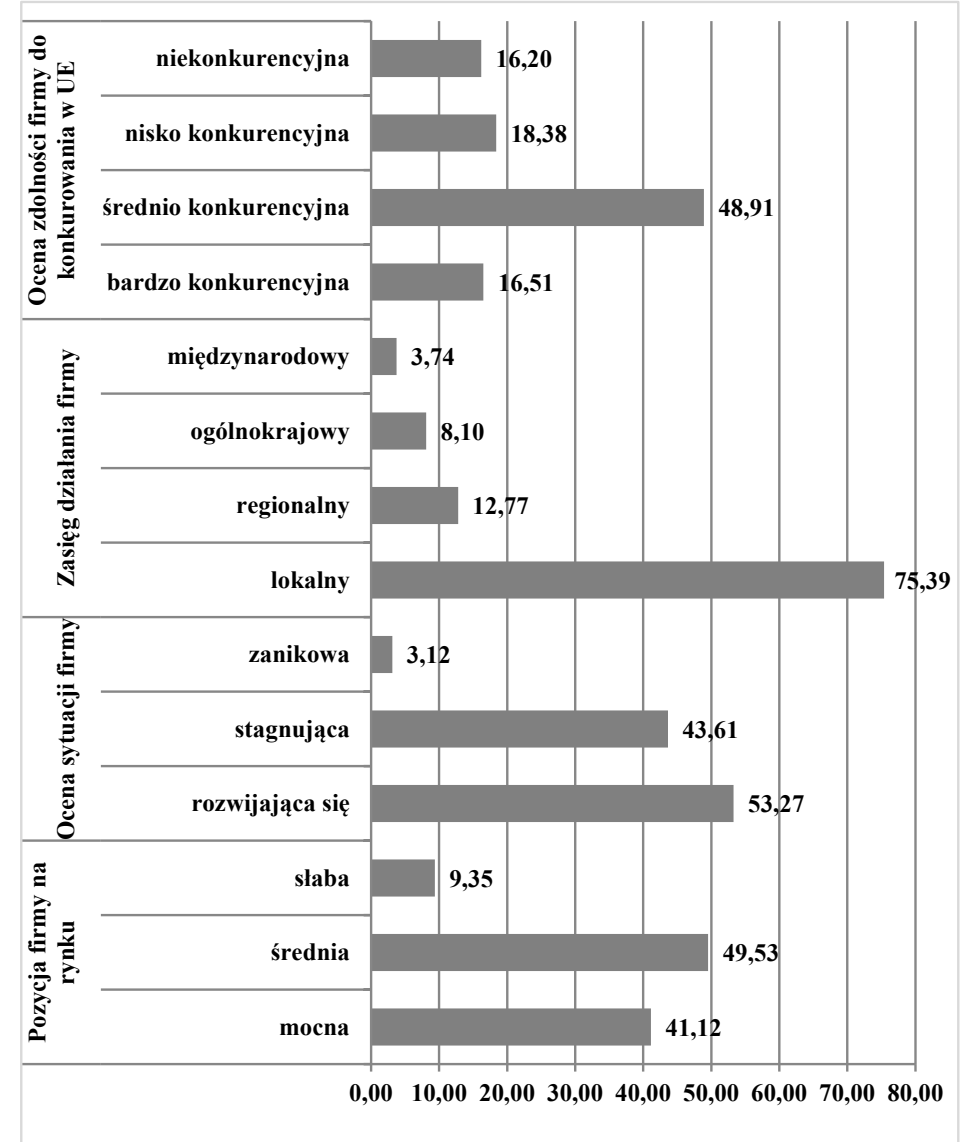

(Źródło: Obliczenia na podstawie wyników własnych badań).

\section{Podstawy decyzyjne zmian asortymentowych - wyniki badań własnych}

Wcześniej publikowane wyniki badań własnych wskazują, że asortyment podkarpackich przedsiębiorstw handlowych zdominowały artykuły sprawdzone, chętnie nabywane przez konsumentów. Nowości asortymentowe traktowane są raczej jako uzupełnienie dotychczasowej oferty, a nie jako podstawowa orientacja firmy na innowacyjność. To asekuracyjne podejście okazywało się przynosić pozytywne wyniki w poziomie bieżącej rentowności sprzedaży. Wyższą skłonnością 
do innowacyjności w polityce asortymentowej cechowały się jednak podmioty o optymistycznych ocenach dotyczących pozycji rynkowej, perspektyw rozwoju oraz zdolności do konkurowania na rynku UE. Podmioty, które decydowały się na wprowadzanie do oferty nowości, realizowały takie zamierzenia co najmniej raz w miesiącu, a częstotliwość ta była wyższa w przedsiębiorstwach o mocnej pozycji rynkowej, dużej skali i zasięgu działania (Cyrek, 2018). Badani przedsiębiorcy, wprowadzając do oferty nowe produkty żywnościowe, uwzględniali głównie opinie konsumentów. W przypadku kosmetyków i produktów chemicznych kierowano się propozycjami hurtowników, zaś podstawę decyzji o nowościach w asortymencie AGD stanowiły oferty producentów (Cyrek, 2017).

Wyniki te można rozszerzyć o bardziej szczegółowe analizy źródeł i sposobów poszukiwania rozwiązań innowacyjnych w przedsiębiorstwach handlu detalicznego (tabela 1). Ogólne spostrzeżenie pozwala uznać badane firmy za podmioty innowacyjne. $\mathrm{W}$ dwóch trzecich spośród nich poszukiwano produktów, których dotychczas nie sprzedawano, a które mogłyby cieszyć się uznaniem klientów. Co więcej, można wnioskować o spontanicznym, niezaplanowanym sposobie określania potencjalnych innowacji asortymentowych. W dominującej większości poszukiwano ich poprzez rozmowę z klientami. Nieco ponad 6\% menedżerów inspirowało się w tych działaniach analizą paragonów kasowych, a w co dwudziestej firmie - wynikami badań ankietowych.

Większą skłonnością do poszukiwania potencjalnie atrakcyjnych dla klientów towarów, nieoferowanych do tej pory w sklepie, cechowali się handlowcy z terenów wsi, którzy jednak wykorzystywali do tego niemal wyłącznie bezpośrednie relacje interpersonalne. W mieście dwukrotnie częściej niż na wsi wykorzystywano zaś analizę paragonów kasowych, a niemal trzykrotnie częściej - badania ankietowe.

Odsetek menedżerów firm handlowych poszukujących nowości asortymentowych wzrastał wraz z wielkością przedsiębiorstwa, a także wraz ze wzrostem wskaźnika rentowności przychodów brutto, jednak dopiero w grupach od II do IV. W grupie o najniższych wynikach najczęściej $(86,2 \%)$ poszukiwano nowych towarów, które poprzez zwiększoną sprzedaż mogłyby poprawić relację zysku do obrotu. Podobne tendencje zaobserwowano w odniesieniu do rozmów z klientami. Rangę bezpośredniego kontaktu dostrzegano zarówno w firmach o najwyższych, jak i najniższych wskaźnikach rentowności. Analizie paragonów kasowych więcej uwagi poświęcano w podmiotach o rentowności poniżej średniej, podczas gdy w firmach najbardziej rentownych badania ankietowe doceniano dwukrotnie częściej niż w pozostałych. 
Tabela 1. Motywy zmian asortymentowych w badanych firmach (według kryteriów obiektywnych) [\%]

\begin{tabular}{|c|c|c|c|c|c|c|c|c|c|c|}
\hline \multirow[b]{2}{*}{ Wyszczególnienie } & \multirow{2}{*}{ 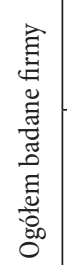 } & \multicolumn{2}{|c|}{$\begin{array}{c}\text { Miejsce } \\
\text { funkcjono- } \\
\text { wania }\end{array}$} & \multicolumn{3}{|c|}{$\begin{array}{l}\text { Liczba osób } \\
\text { pracujących }\end{array}$} & \multicolumn{4}{|c|}{$\begin{array}{l}\text { Grupa rentowności } \\
\text { przychodów brutto }\end{array}$} \\
\hline & & $\begin{array}{l}\text { mia- } \\
\text { sto }\end{array}$ & wieś & do 9 & $\begin{array}{c}10- \\
49\end{array}$ & $\begin{array}{l}50 \\
\text { i wię- } \\
\text { cej }\end{array}$ & I & II & III & IV \\
\hline Firmy ogółem & 100,0 & 100,0 & 100,0 & 100,0 & 100,0 & 100,0 & 100,0 & 100,0 & 100,0 & 100,0 \\
\hline $\begin{array}{l}\text { W tym poszukujące produktów, } \\
\text { których dotychczas nie } \\
\text { sprzedawano, a mogłyby } \\
\text { cieszyć się zainteresowaniem } \\
\text { klientów }\end{array}$ & 67,9 & 66,0 & 70,9 & 64,4 & 77,0 & 81,8 & 86,2 & 61,5 & 65,5 & 66,7 \\
\hline \multicolumn{11}{|l|}{ W tym poprzez: } \\
\hline - rozmowę z klientami & 88,5 & 85,2 & 93,3 & 91,4 & 78,9 & 100,0 & 88,0 & 86,7 & 89,1 & 92,1 \\
\hline - analizę paragonów kasowych & 6,4 & 8,6 & 3,3 & 5,3 & 10,5 & 0,0 & 8,0 & 8,0 & 3,6 & 5,3 \\
\hline - badania ankietowe & 4,6 & 6,3 & 2,2 & 1,3 & 12,3 & 11,1 & 4,0 & 4,0 & 3,6 & 7,9 \\
\hline - inne & 4,6 & 4,7 & 4,4 & 3,9 & 5,3 & 11,1 & 6,0 & 6,7 & 3,6 & 0,0 \\
\hline $\begin{array}{l}\text { Firmy nieposzukujące } \\
\text { produktów, których dotychczas } \\
\text { nie sprzedawano }\end{array}$ & 32,1 & 34,0 & 29,1 & 35,6 & 23,0 & 18,2 & 13,8 & 38,5 & 34,5 & 33,3 \\
\hline \multicolumn{11}{|l|}{ W tym z powodu: } \\
\hline - małej powierzchni sklepu & 55,3 & 51,5 & 62,2 & 61,9 & 29,4 & 0,0 & 62,5 & 44,7 & 65,5 & 63,2 \\
\hline $\begin{array}{l}\text { - wystarczającego asortymentu } \\
\text { sklepu }\end{array}$ & 42,7 & 43,9 & 40,5 & 38,1 & 64,7 & 50,0 & 37,5 & 51,1 & 34,5 & 36,8 \\
\hline $\begin{array}{l}\text { - konieczności „zamrożenia” } \\
\text { gotówki }\end{array}$ & 3,9 & 4,5 & 2,7 & 3,6 & 0,0 & 50,0 & 0,0 & 6,4 & 3,4 & 0,0 \\
\hline
\end{tabular}

(Źródło: obliczenia na podstawie wyników badań własnych).

Podmioty, które nie zadawały sobie trudu poszukiwania nowych produktów mogących trafić do ofert sklepu, motywowały takie stanowisko małą powierzchnią oraz wystarczającym asortymentem. Rzadkim uzasadnieniem pasywnej postawy była także konieczność „zamrożenia” gotówki. W przypadku firm funkcjonujących na wsi relatywnie większą barierą - w porównaniu z ich miejskimi odpowiednikami - okazywała się wielkość sklepu, podczas gdy w miastach, częściej niż na wsi, rezygnowano z nowych pozycji asortymentu ze względu na wystarczający zakres produktów oraz konieczność zamrożenia gotówki. Nie zaskakuje malejące znaczenie zbyt małej powierzchni sklepu jako destymulanty wprowadzania nowości asortymentowych wraz ze wzrostem wielkości firmy, mierzonej liczbą osób pracujących, co wynika ze związku między liczbą osób pracujących a powierzchnią sprzedażową sklepów. Podmioty handlowe 
mikroskali relatywnie rzadziej niż więksi konkurenci wskazywały na wystarczający asortyment. W największych spośród badanych firm jako ograniczenie w modernizacji asortymentu, polegającej na wprowadzeniu do niego nowych pozycji, równie często, jak wystarczający asortyment, wskazywano konieczność racjonalnego gospodarowania gotówką. $\mathrm{O}$ ile z poszukiwania nowych pozycji asortymentu rezygnowała około $1 / 3$ firm $w$ grupach rentowności od II do IV, to podmioty najsłabsze decydowały się na pasywne postawy znacznie rzadziej, motywując je wyłącznie zbyt małą powierzchnią sklepu bądź wystarczającym zakresem asortymentu.

Klasyfikacja badanych podmiotów oparta na kryteriach subiektywnych (tabela 2) również pozwala na wyróżnienie prawidłowości pomiędzy oceną pozycji rynkowej i sytuacji firmy a wprowadzaniem nowych pozycji asortymentowych.

Tabela 2. Motywy zmian asortymentowych w badanych firmach (według kryteriów subiektywnych) [\%]

\begin{tabular}{|c|c|c|c|c|c|c|c|}
\hline \multirow[b]{2}{*}{ Wyszczególnienie } & \multirow{2}{*}{ 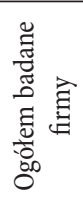 } & \multicolumn{3}{|c|}{$\begin{array}{l}\text { Pozycja firmy na } \\
\text { rynku: }\end{array}$} & \multicolumn{3}{|c|}{ Ocena sytuacji firmy: } \\
\hline & & $\begin{array}{l}\stackrel{\Xi}{\Xi} \\
\stackrel{\Xi}{\Xi} \\
\text { I }\end{array}$ & 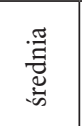 & $\frac{\widetilde{\tilde{m}}}{\frac{\pi}{\omega}}$ & 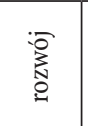 & 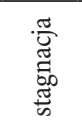 & 䒜 \\
\hline Firmy ogółem & 100,0 & 100,0 & 100,0 & 100,0 & 100,0 & 100,0 & 100,0 \\
\hline $\begin{array}{l}\text { W tym poszukujące produktów, których } \\
\text { dotychczas nie sprzedawano, a mogłyby } \\
\text { cieszyć się zainteresowaniem klientów }\end{array}$ & 67,9 & 76,5 & 64,8 & 46,7 & 73,7 & 62,9 & 40,0 \\
\hline \multicolumn{8}{|l|}{ W tym poprzez: } \\
\hline - rozmowę z klientami & 88,5 & 82,2 & 93,2 & 100,0 & 87,3 & 89,8 & 100,0 \\
\hline - analizę paragonów kasowych & 6,4 & 10,9 & 2,9 & 0,0 & 7,9 & 4,5 & 0,0 \\
\hline - badania ankietowe & 4,6 & 7,9 & 1,9 & 0,0 & 7,9 & 0,0 & 0,0 \\
\hline - inne & 4,6 & 5,0 & 4,9 & 0,0 & 2,4 & 8,0 & 0,0 \\
\hline $\begin{array}{l}\text { Firmy nieposzukujące produktów, } \\
\text { których dotychczas nie sprzedawano }\end{array}$ & 32,1 & 23,5 & 35,2 & 53,3 & 26,3 & 37,1 & 60,0 \\
\hline \multicolumn{8}{|l|}{ W tym $\mathrm{z}$ powodu: } \\
\hline - małej powierzchni sklepu & 55,3 & 32,3 & 58,9 & 87,5 & 33,3 & 73,1 & 66,7 \\
\hline - wystarczającego asortymentu sklepu & 42,7 & 64,5 & 39,3 & 12,5 & 62,2 & 26,9 & 33,3 \\
\hline - konieczności „zamrożenia” gotówki & 3,9 & 9,7 & 1,8 & 0,0 & 6,7 & 1,9 & 0,0 \\
\hline
\end{tabular}

(Źródło: obliczenia na podstawie wyników badań własnych).

Zarówno pogarszająca się ocena pozycji rynkowej, jak i perspektyw rozwojowych firmy wiązała się z malejącym zainteresowaniem nowymi produktami w kompozycji asortymentu. Poprawa pozycji firmy wynikać mogła przy tym z ograniczenia roli przypisywanej rozmowie z klientami na korzyść wzrostu rangi analizy paragonów oraz badań ankietowych. Analogiczne zależności dostrzec 
należy również w przypadku subiektywnie ocenianej perspektywy firmy, gdzie optymizm skłaniał do traktowania rozmów z klientami jako mniej istotnego źródła informacji i skupienia nieco większej uwagi na roli paragonów kasowych oraz badań ankietowych, a więc zaplanowanych i systematycznych sposobach poszukiwania nowości.

Wraz ze spadkiem pozycji rynkowej firmy, rezygnację z poszukiwania nowych pozycji asortymentowych motywowano coraz częściej małą powierzchnią sklepu, rzadziej wskazując na wystarczający asortyment i konieczność zamrożenia gotówki. Menedżerowie firm rozwijających się dwukrotnie rzadziej niż konkurenci wskazywali na ograniczenie w postaci zbyt małej powierzchni sklepu, ale dwukrotnie częściej odwoływali się do wystarczającego asortymentu sklepu. Większy optymizm dotyczący rozwoju firmy łączył się ponadto z przekonaniem o konieczności racjonalnego gospodarowania gotówką.

Kontekst zasięgu działania oraz funkcjonowania w warunkach otwartego rynku europejskiego (tabela 3) również różnicuje zachowania w zakresie kształtowania kompozycji asortymentowej.

Tabela 3. Motywy zmian asortymentowych w badanych firmach według zasięgu działania i zdolności konkurowania w warunkach rynku UE [\%]

\begin{tabular}{|c|c|c|c|c|c|c|c|c|c|}
\hline \multirow[b]{2}{*}{ Wyszczególnienie } & \multirow[b]{2}{*}{ 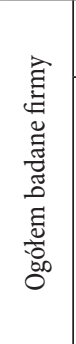 } & \multicolumn{4}{|c|}{ Zasięg działania } & \multicolumn{4}{|c|}{$\begin{array}{c}\text { Zdolność do konkurowania } \\
\text { w warunkach rynku UE }\end{array}$} \\
\hline & & 决 & 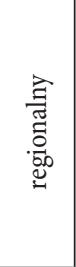 & 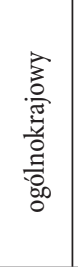 & 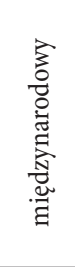 & 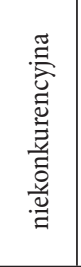 & 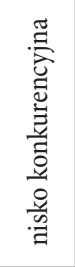 & 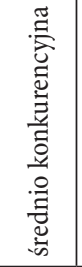 & 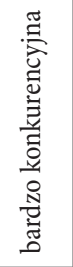 \\
\hline Firmy ogółem & 100,0 & 100,0 & 100,0 & 100,0 & 100,0 & 100,0 & 100,0 & 100,0 & 100,0 \\
\hline $\begin{array}{l}\text { W tym poszukujące produktów, } \\
\text { których dotychczas nie } \\
\text { sprzedawano, a mogłyby cieszyć } \\
\text { się zainteresowaniem klientów }\end{array}$ & 67,9 & 69,0 & 73,2 & 38,5 & 91,7 & 57,7 & 55,9 & 75,8 & 67,9 \\
\hline \multicolumn{10}{|l|}{ W tym poprzez: } \\
\hline - rozmowę z klientami & 88,5 & 92,8 & 86,7 & 80,0 & 36,4 & 90,0 & 93,9 & 91,6 & 72,2 \\
\hline - analizę paragonów kasowych & 6,4 & 4,2 & 10,0 & 0,0 & 36,4 & 3,3 & 6,1 & 5,0 & 13,9 \\
\hline - badania ankietowe & 4,6 & 2,4 & 3,3 & 30,0 & 18,2 & 0,0 & 0,0 & 5,0 & 11,1 \\
\hline - inne & 4,6 & 4,8 & 3,3 & 0,0 & 9,1 & 6,7 & 0,0 & 5,0 & 5,6 \\
\hline $\begin{array}{l}\text { Firmy nieposzukujące } \\
\text { produktów, których dotychczas } \\
\text { nie sprzedawano }\end{array}$ & 32,1 & 31,0 & 26,8 & 61,5 & 8,3 & 42,3 & 44,1 & 24,2 & 32,1 \\
\hline \multicolumn{10}{|l|}{ W tym z powodu: } \\
\hline - małej powierzchni sklepu & 55,3 & 65,3 & 36,4 & 25,0 & 0,0 & 72,7 & 57,7 & 63,2 & 11,8 \\
\hline
\end{tabular}




\begin{tabular}{|l|r|r|r|r|r|r|r|r|r|}
\hline $\begin{array}{l}\text { - wystarczającego asortymentu } \\
\text { sklepu }\end{array}$ & 42,7 & 34,7 & 54,5 & 68,8 & 100,0 & 31,8 & 38,5 & 36,8 & 76,5 \\
\hline $\begin{array}{l}\text { - konieczności „Zamrożenia” } \\
\text { gotówki }\end{array}$ & 3,9 & 4,0 & 0,0 & 6,3 & 0,0 & 0,0 & 3,8 & 5,3 & 5,9 \\
\hline
\end{tabular}

(Źródło: obliczenia na podstawie wyników badań własnych).

Wyższa skłonność do poszukiwania nowości w kompozycji asortymentowej wśród przedsiębiorców realizujących działalność lokalnie lub regionalnie niż na skalę ogólnokrajową, wynikała po części z ich uprawnień decyzyjnych. Prowadząc własne firmy, sami ponoszą ryzyko dotyczące błędnych decyzji w zakresie szerokości i głębokości asortymentu. Badane podmioty, deklarujące ogólnokrajowy zasięg działania, funkcjonowały głównie w ramach form sieciowych, w tym franczyzy, co prowadziło do zmniejszenia autonomii w ustalaniu asortymentu. Wysoki odsetek podmiotów aktywnych w bieżącym komponowaniu oferty wśród podmiotów operujących na skalę międzynarodową wynika po części z konstrukcji ich struktur organizacyjnych, obejmujących odrębne komórki odpowiedzialne za starania dotyczące kompozycji asortymentowych.

Wraz ze wzrostem obszaru działania, jako sposób identyfikacji produktów, które można by wprowadzić do sprzedaży, traciły na znaczeniu rozmowy z klientami, zyskiwały natomiast formy bardziej sformalizowane, jak badania ankietowe. W przypadku podmiotów rezygnujących z modernizacji asortymentu decyzje te warunkowano zbyt małą powierzchnią sklepu, która jednak traciła na znaczeniu wraz ze wzrostem obszaru oddziaływania firmy, przeciwnie do wystarczającego asortymentu, który akcentowano w 34,7\% firm prowadzących sprzedaż wyłącznie lokalnie i we wszystkich firmach działających międzynarodowo.

Asortyment pod kątem potencjalnych innowacji chętniej analizowano w podmiotach deklarujących co najmniej średnią zdolność do konkurowania na otwartym rynku europejskim. W firmach bardzo konkurencyjnych decyzje o wprowadzeniu nowych towarów podejmowano na podstawie szerszego niż w pozostałych przedsiębiorstwach zakresu podstaw informacyjnych. W firmach tych relatywnie najczęściej deklarowano ponadto, że dysponują wystarczająco bogatym asortymentem, którego nie trzeba powiększać. Dodatkowo wraz z poprawą subiektywnie ocenianej zdolności do konkurowania, firmy częściej wskazywały konieczność zamrożenia gotówki jako destymulantę wprowadzania do asortymentu nowości. 


\section{Podsumowanie}

W badanych przedsiębiorstwach handlowych, realizujących działalność w województwie podkarpackim, poszukiwanie produktów, których dotychczas nie sprzedawano, a które mogłyby cieszyć się zainteresowaniem klientów, było zjawiskiem powszechnym. Aktywność taką wykazywano w 2/3 badanych podmiotów. Działanie to było przy tym domeną przedsiębiorstw największych pod względem liczby osób pracujących i o największej skali oddziaływania geograficznego, o mocnej pozycji rynkowej, rozwijających się, o średniej lub wysokiej zdolności do konkurowania w warunkach otwartego rynku UE, a jednocześnie o najniższych wskaźnikach rentowności przychodów. Pozostaje to w zgodzie z teoretycznym założeniem o wpływie atrakcyjnego dla klientów asortymentu na ich skłonność do zakupów w placówce oferującej bogaty wybór i wprowadzającej nowości do kompozycji asortymentowej, a przez to - na pozycję rynkową przedsiębiorstwa. Realizacja takiej strategii prawdopodobnie związana jest jednak ze wzrostem kosztów, co skutkować może niższym wskaźnikiem rentowności przychodów. Przeprowadzone badania nie dowodzą, że czynnikiem określającym poziom rentowności lub inne wskaźniki pozycji rynkowej przedsiębiorstwa, są działania w zakresie wprowadzania nowych pozycji asortymentowych do oferty placówki handlowej. Wskazują jednak, że schematy zachowań podmiotów o odmiennych wynikach ekonomicznych różnią się, co skłania do poszukiwań potencjalnych dwukierunkowych związków między decyzjami asortymentowymi a rezultatami rynkowymi. Deterministyczny charakter takich relacji nie jest jednoznaczny wobec znacznej liczby czynników wpływających na wyniki podmiotów handlowych. Wśród tych czynników znajdują się również specyficzne rozwiązania w zakresie realizowanych strategii konkurowania, w tym związane z wyborami modelu biznesowego, formatu placówki, lokalizacji, działań promocyjnych, polityki cenowej. Stanowią one obszar wymagający dalszych pogłębionych badań.

Przedstawione wyniki wskazują również na zasadność identyfikacji źródeł sukcesu w zakresie wdrażania nowych produktów do oferty, w sposobach realizacji takich działań i ich przesłankach informacyjnych. Fakt, że zdecydowana większość przedsiębiorców kończy poszukiwanie odpowiedzi o asortyment, który potencjalnie zyskałby aprobatę nabywców, na rozmowie z klientami może prowadzić do suboptymalnych wyników tych podmiotów. Wniosek ten jest tym bardziej prawdopodobny, że to podmioty o najmocniejszej pozycji rynkowej i zdolności do konkurowania na rynku UE oraz rozwijające się relatywnie najczęściej wykorzystywały także inne niż bezpośrednie rozmowy z klientami formy poszukiwania nowych pozycji asortymentu, takie jak analiza paragonów czy 
badania ankietowe. Podmioty najbardziej rentowne natomiast, w porównaniu do tych o niższych wskaźnikach relacji zysku do przychodów, najczęściej wykorzystywały zarówno bezpośredni kontakt werbalny z klientami, jak i ankiety.

Prezentowane badania zwracają także uwagę na podstawowe bariery wdrażania nowych pozycji do asortymentu handlowego. Pasywność w poszukiwaniach nowych produktów z przeznaczeniem na wzbogacenie asortymentu motywowano najczęściej zbyt małą powierzchnią sklepu. Znaczenie tego czynnika odgrywało jednak najmniejszą rolę, zarówno wśród podmiotów o silnej pozycji rynkowej, wysokiej zdolności do konkurowania, jak i rozwijających się. W przedsiębiorstwach takich większą rolę przywiązywano do braku potrzeby rozwoju asortymentu związanego z oceną, że dotychczas oferowany zakres produktów jest wystarczający. W firmach tych częściej niż w pozostałych podgrupach klasyfikacyjnych zwracano uwagę na konieczność zamrożenia gotówki, czyli na czynnik, który nie miał z kolei żadnego znaczenia dla firm najbardziej rentownych. Przełamanie wielu z tych ograniczeń może wymagać od handlowców zmian w sposobach organizacji działalności, w tym logistyki zamówień i dostaw czy sposobów prezentacji oferty, również opartej na nowych technologiach. Tym samym pozornie niewielka zmiana podejścia do kształtowania asortymentu może być podstawą wdrażania zasadniczej innowacji handlowej.

Sformułowane w opracowaniu konkluzje sygnalizują istnienie specyficznych współzależności między wynikami podmiotów handlowych a decyzjami asortymentacyjnymi. Określenie tych zależności nie ma jednak charakteru deterministycznego i uniwersalnego, lecz dotyczy wyłącznie podmiotów handlowych prowadzących działalność w województwie podkarpackim. Region ten, ze względu na swoje cechy związane z poziomem rozwoju gospodarczego oraz uwarunkowaniami demograficznymi czy kulturowymi zachowań zakupowych, charakteryzuje się specyficzną strukturą handlu detalicznego, a działania handlowców wymagają uwzględnienia tych warunków. Istnieje więc potrzeba prowadzenia badań w zakresie decyzji asortymentowych detalistów o charakterze ogólnokrajowym, które pozwolą na szerszą weryfikację sformułowanych sygnalnie prawidłowości.

\section{Bibliografia}

Cox, R., \& Brittain, P. (2000). Zarządzanie sprzedaża detaliczną. Warszawa, Polska: PWE. Cyrek, P. (2018). Częstotliwość zmian w asortymencie przedsiębiorstw handlu detalicznego żywnością. Handel Wewnętrzny, 3(374), maj-czerwiec, 94-105. 
Cyrek, P. (2017). Motywy wprowadzania nowych pozycji asortymentowych w podmiotach handlu detalicznego żywnością. Marketing i Zarządzania, 2(48), 227-287. doi: 10.18276/miz.2017.48-26.

Dekimpea, M. G., Gielens, K., Raju, J., \& Thomase, J. S. (2011). Strategic Assortment Decisions in Information-Intensive and Turbulent Environments. Journal of Retailing, 87(1), S17-S28.

Diehl, K., \& Poynor, C. (2010). Great Expectations?! Assortment Size, Expectations, and Satisfaction. Journal of Marketing Research, 67, kwiecień, 312-322.

Grzesiuk, A. (2000). Trafić z asortymentem. Marketing w Praktyce, 3(31), 35-38.

Hutt, M. D., \& Speh, T. W. (1997). Zarządzanie marketingiem. Warszawa, Polska: PWN.

Kłosiewicz-Górecka, U. (2014). Zmiany w handlu w okresie spowolnienia gospodarczego. Marketing i Rynek, 7, 2-13.

Kobyłt, A. (2006). Kategoria produktów w jednostkach handlowych. Logistyka i Transport, 1(2), 27-33.

Kucharska, B. (2014). Przedsiębiorstwa handlu detalicznego wobec zmian w zachowaniach konsumentów. Marketing i Rynek, 8, 867-872.

Łukasik, P. (2008). Marketing $w$ handlu detalicznym produktami spożywczymi. Lublin, Polska: Wydawnictwo Uniwersytetu Marii Curie-Skłodowskiej.

Mathmanna, F., Chylinski, M., de Ruyterc, K., \& Higgins, E. T. (2017). When Plentiful Platforms Pay Off: Assessment Orientation Moderates the Effect of Assortment Size on Choice Engagement and Product Valuation. Journal of Retailing, 93(2), 212-227. doi: 10.1016/j.jretai.2017.02.001.

Mikołajczyk, J. (2008). Oferta asortymentowo-usługowa. W: M. Sławińska (red.), Kompendium wiedzy o handlu (ss. 128-134). Warszawa, Polska: PWN.

Mruk, H., \& Rutkowski, I. P. (1999). Strategia produktu. Warszawa, Polska: PWE.

Olejniczak, T. (2008). Badanie postrzegania innowacji produktowych na rynku żywności. W: S. Kaczmarczyk \& M. Schulz (red.), Zastosowania badań marketingowych $w$ procesie tworzenia nowych produktów (cena, opakowanie, znak towarowy) (ss. 167-175). Toruń, Polska: Dom Organizatora.

Petrova, S. (2019). Determinants of choice of assortment size at a point of sale. Trakia Journal of Sciences, 17(1), 459-464. doi:10.15547/tjs.2019.s.01.075.

Pilarczyk, B., Sławińska, M., \& Mruk, H. (2001). Strategie marketingowe przedsiębiorstw handlowych. Warszawa, Polska: PWE.

Rajagopal, P. (2008). New Product Introduction and Seasonality Effect in Food Products Retailing. Journal of Food Products Marketing, 14(4), 54-75. doi: lo.1080/10454440801986355. 
Ruiz-Real, J. L., Gázquez-Abad, J. C., Esteban-Millat, I., \& Martínez-López, F. J. (2018). Small vs. Large: how assortment size influences consumer loyalty. Journal of Marketing Trends, 5(2), kwiecień, 43-56.

Shankar, V., \& Yadav, M. S. (2011). Innovations in Retailing - Editorial. Journal of Retailing, 87(1), S1-S2. doi: 10.1016/j.jretai.2011.04.004.

Sławińska, M. (2015). Innowacje marketingowe w działalności przedsiębiorstw handlowych. Annales Universitatis Mariae Curie-Skłodowska, 49(1), 157-167.

Śmigielska, G., \& Wiśniewska, S. (2016). Innowacje marketingowe w handlu detalicznym. Problemy Zarządzania, 14(1), 68-70. doi: 10.7172/1644-9584.57.3.

Tul-Krzyszczuk, A., \& Krajewski, K. (2014). Innowacje w procesach dystrybucji i sprzedaży produktów żywnościowych. Marketing i Rynek, 6, 774-789.

Waniowski, P., Sobotkiewicz, D., \& Daszkiewicz, M. (2010). Marketing. Teoria i przykłady. Warszawa, Polska: Wydawnictwo PLACET.

Whitley, S. C., Trudel, R., \& Kurt, D. (2018). The Influence of Purchase Motivation on Perceived Preference Uniqueness and Assortment Size Choice. Journal of Consumer Research, 45(4), 710-724. doi: 10.1093/jcr/ucyo31.

\section{Streszczenie}

W artykule analizie poddaje się proces zarówno modyfikacji zakresu asortymentowego poprzez identyfikację rozwiązań w procesie wzbogacenia oferty przedsiębiorstw handlu detalicznego żywnością o nowe pozycje towarowe, jak i przyczyny rezygnacji z takich działań.

Podstawę wnioskowania stanowiły wyniki wywiadów bezpośrednich, realizowanych na przełomie 2015 i 2016 roku wśród 321 przedsiębiorców sfery handlu detalicznego, prowadzących działalność gospodarczą w województwie podkarpackim. Analizy prowadzone są zarówno w odniesieniu do ogółu podmiotów, jak i obiektywnych i subiektywnych przekrojów klasyfikacyjnych tych przedsiębiorstw według kryteriów: miejsca prowadzenia działalności, wielkości określonej liczbą pracujących, rentowności przychodów brutto, przestrzennego zasięgu oddziaływania, a ponadto subiektywnie określonej pozycji rynkowej, oceny sytuacji z uwzględnieniem perspektyw rozwojowych i postrzegania zdolności do konkurowania.

Skłonność do poszukiwania pozycji asortymentowych, które mogłyby znaleźć uznanie klientów, była wśród badanych dość powszechna, jednak realizacja tych poszukiwań przybierała relatywnie proste formy. Wykorzystywano głównie bezpośrednie rozmowy z klientami, znacznie rzadziej natomiast metody analityczne. Postawę pasywną motywowano dwoma naczelnymi powodami: małą powierzchnią sklepu oraz przekonaniem o właściwej strukturze asortymentu, uzupełnianymi niekiedy ograniczeniami finansowymi.

SŁOWA KLUCzOWE: handel detaliczny, oferta handlowa, asortyment, modernizacja asortymentu 


\section{Summary}

The paper analyzes the process of modifying the range of assortment by identifying solutions in the process of enriching the offer of food retail companies with new items, as well as the reasons for abandoning such activities.

Conclusions were based on the results of direct interviews conducted in 2015/2016 among 321 entrepreneurs in the sphere of retail trade in Podkarpackie province. Analysis is carried out both in relation to all entities, and taking into account the objective and subjective classification of these enterprises according to such criteria as: place of activity, size determined by the number of employees, profitability of gross revenues, spatial range, as well as subjective market position, assessment of the situation considering development perspectives and perception of ability to compete.

The tendency to search for assortment items that could find customer recognition was quite common among the respondents, however, the implementation of these searches took on relatively simple forms. Mainly, in this case, direct conversations with clients were used, while analytical methods were much rarer. The passive attitude was motivated by two main reasons, which included: the small area of the store and belief in the proper structure of the assortment, which was supplemented by financial restrictions.

KEYWORDS: retail trade, trade offer, assortment, assortment modernization

Kody JEL: L81, M21, M31

\section{Nota o autorze}

Dr Piotr Cyrek - Uniwersytet Rzeszowski, Kolegium Nauk Społecznych, Instytut Ekonomii i Finansów, Katedra Marketingu i Przedsiębiorczości; główne dziedziny działalności naukowej: ekonomia, zarządzanie; e-mail: piotrcyr@univ.rzeszow.pl; ORCID: 00oo-0002-8306-1612. 